\title{
THE REGIONAL DISPARITY OF INFLUENCING FACTORS OF TECHNOLOGICAL INNOVATION IN CHINA: EVIDENCE FROM HIGH-TECH INDUSTRY
}

\author{
Yongli ZHANG ${ }^{1,2^{*}}$ \\ ${ }^{1}$ Hebei Key Laboratory of Strategic Critical Mineral Resources, Hebei GEO University, \\ 050031 Shijiazhuang, Hebei Province, China \\ ${ }^{2}$ School of Management, Hebei GEO University, 050031 Shijiazhuang, Hebei Province, China
}

Received 18 September 2020; accepted 28 February 2021

\begin{abstract}
Accurate analysis of technological innovation mechanism in different regions is the key to promoting China's technological innovation, economic transformation and upgrading. This paper collected statistical data of high-tech enterprises in 27 provinces in China from 2009 to 2016, established a novel PSO-GRNN model, and applied sensitivity analysis to explore the influencing factors and regional differences of enterprise technological innovation in Eastern, Central and Western China. The empirical results showed that the influencing factors were innovation investment, market environment, government support and foreign technology spillover sorting by impact size. Innovation investment was the decisive factor of technological innovation, but innovation resources mainly concentrated on Eastern China, severely insufficient in Central and Western China. Market environment was favorable to Eastern and Central China, but unfavorable to Western China, which restricted greatly the development of Western China. The principalagent problem of state-owned enterprise and the crowding out effect of government research and development funds jointly led to the negative influence of government support on technological innovation. Foreign technology spillover had significant positive effects on technological innovation in Western China. This paper clarifies some disputes about influencing factors of technological innovation and provides a new research perspective for related issues.
\end{abstract}

Keywords: technological innovation, regional disparity, high-tech industry, PSO-GRNN.

JEL Classification: C87, C88, O32, O36.

\section{Introduction}

At present, China's economy enters the "new normal", "innovation-driven growth" is the key to China's future low carbon development, so stimulating the enterprise innovation consciousness to promote economic development through technological progress is the new driving force of China's economy (Li et al., 2020; Xiao et al., 2018; Noesselt, 2017). When the

*Corresponding author. E-mail: zhangyongli086@163.com

Copyright (c) 2021 The Author(s). Published by Vilnius Gediminas Technical University

This is an Open Access article distributed under the terms of the Creative Commons Attribution License (http://creativecommons. org/licenses/by/4.0/), which permits unrestricted use, distribution, and reproduction in any medium, provided the original author and source are credited. 
core mechanisms behind technological innovation in different regions is accurately analyzed and grasped, Chinese governments can make policies and countermeasures according to the geographical location to promote technological innovation, economic transformation and upgrading.

Industrial enterprises are the most essential undertakers of technological innovation. The technological innovation ability of industrial enterprises not only determines the industry technological innovation level of regions located in, and greatly influences the performance of technological innovation in the whole country. On the macro level, technological innovation ability of industrial enterprises is the guarantee for the sustainable development of a national or regional economy. On the micro level, technological innovation can improve enterprise's competitive advantage and increase its market share. Technology innovation ability is the source power China's manufacturing development, and also the core competitiveness of industrial enterprises (Wan et al., 2015; Zhu et al., 2019; Du et al., 2019).

However, technological innovation is a sophisticated system, the influencing factors of technological innovation ability vary in different regions. Two limitations in current researches exist.

Firstly, the factors that affect technological innovation have many controversies, even contradictory viewpoints and research findings. For instance, some scholars believe that research and development $(\mathrm{R} \& \mathrm{D})$ investment will stimulate technological innovation within enterprises (Zhong et al., 2011; Alarcón \& Sánchez, 2013), while others found that R\&D investment is affected by uncertainties such as income and reward period, business opportunities of new products/services, and imitation threat from competitors. Therefore, R\&D investment has both advantages and disadvantages (Demirel \& Mazzucato, 2012; Coad et al., 2016). Some scholars believed that state-owned enterprises were more conducive to technological innovation than other enterprises (Pfeffer \& Salancik, 2003; Hu, 2001), while others found that state-owned enterprise had severe principal-agency problem, that would lead to a decline in innovation efficiency (Li et al., 2010; Zhang \& Shi, 2011). Some scholars believed foreign direct investment (FDI) will bring technology spillover effect and promote local technological progress (Wang et al., 2016; Smith \& Thomas, 2017), while others discovered that FDI had a crowding out effect on technological innovation of local enterprise (Wu et al., 2017; Alfaro, 2016). Some studies found that basic innovations had the attributes of a common product, government $\mathrm{R} \& \mathrm{D}$ fund had a leverage effect on technological innovation (Szczygielski et al., 2017; Guo et al., 2016), while others confirmed that crowding out effect of government fund to enterprise innovation investment (Huang et al., 2016; Hong et al., 2016).

Secondly, multiple linear regression (MLR) preferentially used by previous scholars cannot handle nonlinear problems (Hua et al., 2007). GRNN has strong advantages in nonlinear mapping capability and approximation capability, especially when the data samples are small or unstable (Luo \& Fu, 2013). Meanwhile, the parameters of the neural network have significant influences on prediction performance, however, GRNN only has one extension parameter that needs to be adjusted, therefore, GRNN has good inclusiveness and fast learning ability (Hu et al., 2017; Ladlani et al., 2012).

In this study, statistics of high-tech enterprises in 27 Chinese provinces from 2009 to 2016 were collected, and then the PSO-GRNN model with more precise and robust is established 
by optimizing the SPREAD parameter of GRNN with particle swarm optimization (PSO) algorithm, and finally PSO-GRNN model is employed to analyze spatio-temporal variation of the effects on technological innovation of innovation investment, market environment, government support and foreign technology spillover. This study adopts a new methodological perspective to discover the specific mechanism of various factors affecting technological innovation in Eastern China, Central China and Western China, which clarifies and explains some arguments and contradictions of previous studies, meanwhile, extends the multi-model hybrid application method.

The specific research framework can be divided into the following parts. The literature review and research hypothesis of the relevant studies are described in Section 1. The principle of sensitivity analysis based on artificial neural network and PSO-GRNN model are introduced in Section 2. Indicators and data analysis is given in Section 3. Section 4 is empirical analysis, which makes empirical analysis on the influencing factors of technological innovation in China's high-tech industry. Conclusions and research recommendations are in last Section.

\section{Literature summary and hypotheses}

Enterprise development depends on technological innovation, enterprises are the main undertakers and applicators of technological innovation. R\&D expenditure and R\&D personnel are the main $R \& D$ investments. Some scholars found that $R \& D$ investment can increase innovation output and indirectly improve market share and productivity, R\&D investment is the main driving force of technological innovation within enterprises (Zhong et al., 2011; Alarcón \& Sánchez, 2013; Jefferson et al., 2006; Koc \& Ceylan, 2007). On the contrary, some scholars found that technological innovation is affected by payback time, market opportunities for new products or services, imitation threat of competitors and other factors, innovation activities are full of uncertainty, may bring more profits or losses. Compared with mature enterprises, young enterprises have lower risk tolerance, so technological innovation is a double-edged sword for young enterprises (Demirel \& Mazzucato, 2012; Coad et al., 2016; Wang \& Guo, 2008). Nevertheless, this study formulates the first hypothesis as below.

Hypothesis 1. Innovation investment can promote the development of technological innovation with positive influence, but the effect size is different in different regions.

Local businesses are influenced greatly by market conditions. The regional innovation environment is composed of many factors, such as enterprise scale, market competition and foreign direct investment (FDI).

The effect of enterprise scale on innovation efficiency is less controversial among scholars (Huang et al., 2017; Mei \& Shao, 2016). For instance, Pavitt et al. (1987) argued that enterprise size and innovation efficiency are U-shaped relationships, and the innovation efficiency of large or small enterprises is the highest. Stock et al. (2002) founded that innovation efficiency fell with enterprise size, and the innovation efficiency of small enterprises was the highest. Shefer and Frenkel (2005) believed that R\&D expenditure was affected by enterprise size, large enterprises invested more $R \& D$ funds than small enterprises. 
Different opinions about the impact of market competition on technological innovation efficiency have been argued until present time (Aghion et al., 2005). Some scholars represented by Schumpeter and Backhaus (2003) believed that the higher market concentration, the more enterprise could monopolize $\mathrm{R} \& \mathrm{D}$ revenue, and the stronger innovation motivation, so innovation was tightly associated with monopoly. However, most researchers concluded that market monopoly would stifle enterprise's innovation, only full market competition can promote the development of enterprise technical innovation (Tseng \& Hung, 2013).

Two opposite views exist about the influence of foreign investment on enterprise technological innovation. One view thought that the pressure of market competition brought by foreign capital and the spillover effect of technological innovation indirectly stimulated the innovation vitality of local enterprises (Wang et al., 2016; Smith \& Thomas, 2017). However, another view believed foreign investment would also occupy a certain amount of market sales, when the crowding out effect is formed, it is not conducive to the development of local enterprises and technological innovation (Wu et al., 2017; Alfaro, 2016; Alarcón \& Sánchez, 2013).

These arguments raise a question whether the market environment is negatively correlated with technological innovation and whether there are regional differences. Therefore, this paper continues to reasonably infer the second hypothesis.

Hypothesis 2. Market environment is positively correlated to technological innovation, and there are regional differences in effect size.

Financial incentives from government have important influences on technological innovation activities of enterprises (Lewandowska et al., 2019). There are also two opposing views on the impact of government support funds on technological innovation. Some scholars believed that basic research had the characteristics of public goods with long cycle, high cost, high risk, but unable to monopolize the benefits. Therefore, in the case of market failure, government must give preferential policies and financial subsidies for basic research to reduce costs and risks. Government support fund leveraged the investment of other R\&D funds in basic research, exerting leverage effect (Szczygielski et al., 2017; Guo et al., 2016). On the contrary, some scholars argued that the efficiency of government support funds was lower than that of enterprises' own R\&D funds, and too much government support funds will lead to the decrease of enterprises' own R\&D funds, forming a crowding out effect and reducing the efficiency of enterprises' technological innovation (Huang et al., 2016; Hong et al., 2016).

Knowledge assets are the key factors affecting enterprise innovation (Cho, 2020). The quantity and quality of knowledge and talents reserve for state-owned enterprises is much better than that of non-state-owned enterprises. Meanwhile, state-owned enterprises enjoy more government innovation-stimulating policies. Therefore, state-owned enterprises have inherent advantages in technological innovation (Zhang \& Shi, 2011). However, the principal-agent problem exists in state-owned enterprises, which will lead to the eagerness for quick success and quick profit, the waste of innovative resources and the low efficiency of technological innovation ( $\mathrm{Wu}, 2008)$.

Considering the innovation resource advantage and the principal-agent problem for stateowned enterprises exist simultaneously, this study formulates the third hypothesis as below. 
Hypothesis 3. Government support limits the development of technological innovation to a certain extent, and the restriction effect varies in regions.

Generally, technology development of one region usually goes through three stages: technology introduction or purchase, imitation innovation and independent innovation. Independent innovation is the original innovation and re-innovation on the basis of technology introduction and absorption. FDI and technology purchase will bring about the introduction and absorption of foreign technology, form technology spillover effect, and promote local enterprises from imitation innovation to independent innovation (Lin \& Zhang, 2006; Dazheng, 2009; Li \& Shen, 2011). While some researchers discovered that FDI had crowding out effects on technological innovation of local enterprise (Wu et al., 2017; Alfaro, 2016). About the dispute over spillover or crowding out effect of foreign technology, the fourth hypothesis in this study is stated as follows.

Hypothesis 4. Foreign technology spillover plays a driving role in technological innovation, but the driving effect size is different due to regional differences.

\section{Methods}

\subsection{Sensitivity analysis based on artificial neural network}

Sensitivity analysis assumes that the model is $y=f\left(x_{1}, x_{2}, \ldots, x_{n}\right)\left(x_{i}\right.$ is the $i^{t h}$ input attribute of the model), each input attribute changes within the possible value range to predict the effect on the output value. The effect size is called the sensitivity coefficient. The greater the sensitivity coefficient, the higher the influence of input attribute on output value.

Since the sensitivity analysis is operated on the basis of the modeling approaches, according to the modeling approaches, sensitivity analysis can be divided into two categories: modeled sensitivity analysis and modeless sensitivity analysis. In the early studies, scholars used statistical methods to establish the model, and the most common model was multiple linear regression. With the emergence of various problems in different research fields, the statistical modeling approach gradually exposes its limitations, scholars begin to adopt artificial neural network (ANN) to establish the sensitivity analysis model. The ANN model does not need prior knowledge and functional relationship between variables. After determining input and output variables and data, it can be self-learning and self-organizing, with strong robustness and generalization ability (Marchioni \& Magni, 2018; Cao et al., 2017).

However, the shortcoming of ANN model is poor interpretation or explanation, it is a black-box problem, therefore, how to illuminate the "black box" is the key to use the sensitivity analysis based on artificial neural network. In this study, the mean impact value (MIV) method is described for understanding the mechanics of ANNs. In 1995, MIV was discovered and proposed by Dombi et al., which was later regarded by most scholars as one of the best ways to assess the correlation of variables (Jiang et al., 2013). The sensitivity analysis process based on ANN model and MIV indicator is as follows.

First, the source data is divided into training data and testing data to establish the ANN model and verify the accuracy of the model respectively. Then, two data samples $P_{1}$ and $P_{2}$ 
are formed by selecting one input variable whose source data increases and decreases by $10 \%$ respectively, while the data of other variables remain unchanged. Finally, data samples $P_{1}$ and $P_{2}$ are input into the ANN model, and two simulation results $A_{1}$ and $A_{2}$ are obtained. The difference between $A_{1}$ and $A_{2}$ is the impact value (IV) of the input variable on output variable, and the average value of IV is named mean impact value (MIV) for the variable. The MIV indicators of other input variables are solved similarly. Therefore, MIV indicator can be applied to measure the impact of input variables on output variables, and its symbol and absolute value represent the impact direction and size respectively.

MIV method illuminates the "black box" of ANN model to make the results of ANN model interpretable. Furthermore, ANN model has strong predictive ability, which makes it become a powerful quantitative tool for forecasting, evaluating and explaining economic and management phenomena.

\subsection{PSO-GRNN model}

Generalized regression neural network (GRNN) is a radial basis function (RBF) network proposed by Specht (1991), an American scholar, with strong nonlinear mapping and approximation ability. At the same time, GRNN only needs to adjust one parameter, so its calculation speed is fast. GRNN also has strong adaptability for uncertain data and small sample data.

The SPREAD parameter of GRNN has a great influence on its prediction accuracy. In order to search for the best parameters, scholars (Holland, 1992; An et al., 2018; Kennedy \& Eberhart, 1995) have proposed various optimization algorithms, such as fruit fly optimization algorithm (FOA), genetic algorithm (GA), particle swarm optimization (PSO), etc. In this study, particle swarm optimization (PSO) algorithm is selected as the optimization algorithm, so a PSO-GRNN model is established for sensitivity analysis.

The effect size and direction of factors that influence technological innovation are calculated by using MIV and PSO-GRNN model, as shown in Figure 1.

The main calculation steps are as follows.

Step 1: Initializing particles and velocities

Each SPREAD parameter of GRNN is encoded as one particle to form the initial particle swarm $X=\left\{X_{1}, X_{2}, \ldots, X_{N}\right\}$, each particle has a velocity, the velocity of particle swarm is initialized as $V_{i}=\left\{v_{i 1}, v_{i 2}, \ldots, v_{i n}\right\}$.

Step 2: Calculating the particle fitness

After the PSO-GRNN model is trained and tested, the total absolute error between predicted and observed value of testing sample is taken as the fitness value of each particle. The calculation equation is shown as follows.

$$
F=\sum_{i=1}^{n} a b s\left(y_{i}-o_{i}\right) .
$$

In the Eq. (1), $n$ is the sample size, $y_{i}$ and $o_{i}$ respectively represent the observed and predicted values of sample $i$. 


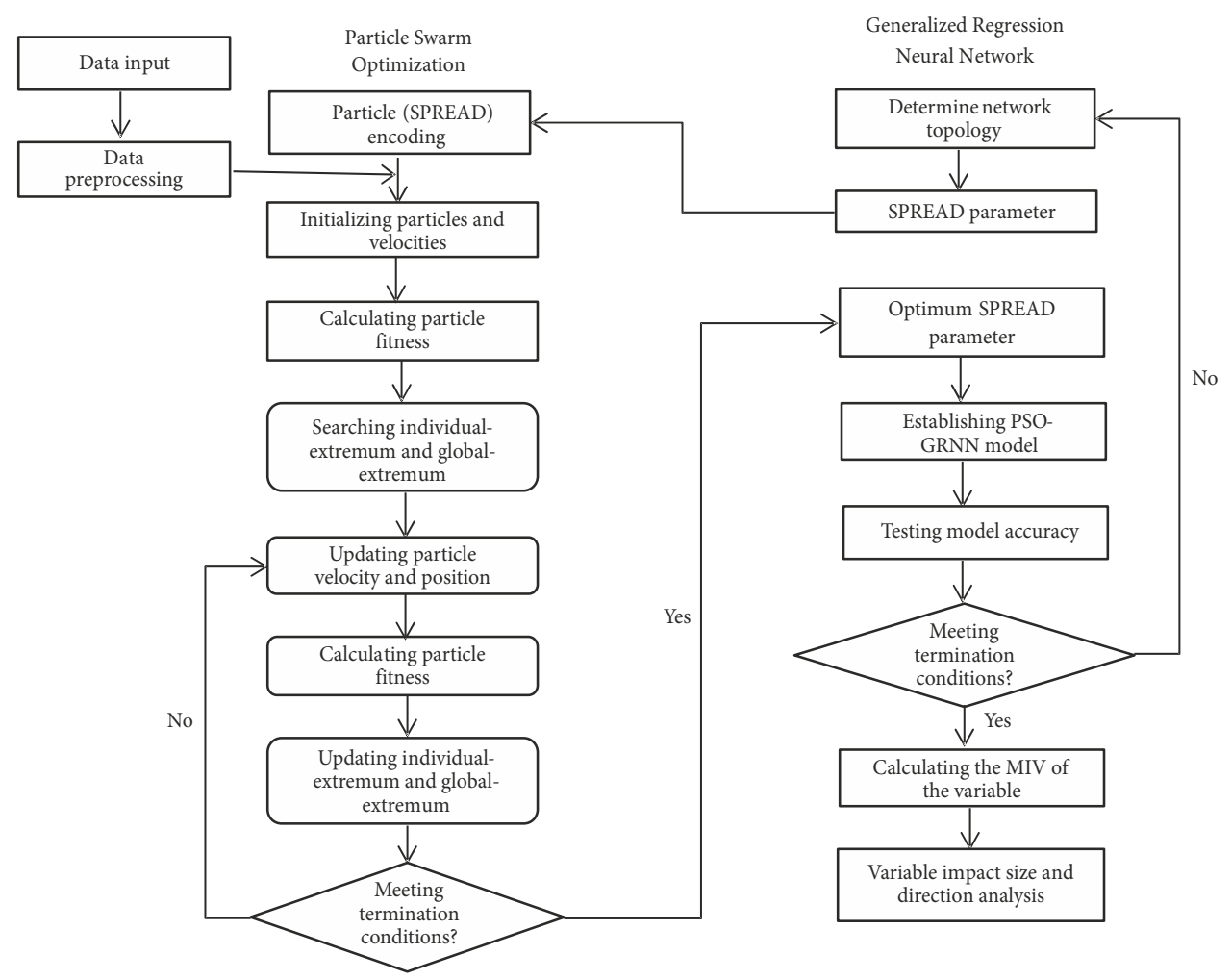

Figure 1. The calculation process of PSO-GRNN model

Step 3: Determining the individual-extremum and global-extremum

According to the fitness function, the fitness value of each particle's position is calculated. Assuming that the individual-extremum of particle $i$ is $P_{i}=\left[P_{i 1}, P_{i 2}, \ldots, P_{i D}\right]$, the globalextremum is $P_{g}=\left[P_{g 1}, P_{g 2}, \ldots, P_{g D}\right]$.

Step 4: Updating the particle velocity and position

The velocity and position of each particle are constantly updated through individual and global extremum, the calculation equations are shown in Eq. (2) and (3).

$$
\begin{aligned}
& v_{i d}(t+1)=\omega v_{i d}(t)+\eta_{1} \operatorname{rand}()\left(p_{i d}-x_{i d}(t)\right)+\eta_{2} \operatorname{rand}()\left(p_{g d}-x_{i d}(t)\right) ; \\
& x_{i d}(t+1)=x_{i d}(t)+v_{i d}(t+1) .
\end{aligned}
$$

Step 5: Establishing the PSO-GRNN model

After decoding the optimal population particle searched by particle swarm optimization (PSO), the optimal SPREAD parameter of GRNN network is obtained, and then the PSOGRNN model is established. 
Step 6: Calculating the MIV of each variable

Increasing and decreasing the original value of one independent variable to form two new data samples, while the original value of other independent variables remains unchanged. Two new samples were input into the PSO-GRNN model for simulation and prediction, the average difference between the predicted values of the two new samples is the MIV of the variable. The absolute value of MIV indicates the effect size of the variable, and the positive or negative value of MIV indicates the effect direction of the variable.

\section{Indicators and data}

\subsection{Influencing factors and measurement indicators}

On the basis of previous researches, this study assumes that there are three forces throughout the technological innovation process of industrial enterprises; they are central driving force, internal driving force and external driving force. Central driving force mainly includes the $\mathrm{R} \& \mathrm{D}$ expenditure and $\mathrm{R} \& \mathrm{D}$ employee, etc. Internal driving force mainly includes enterprise scale, property right structure, R\&D expenditure structure, etc. External driving force mainly includes foreign direct investment (FDI), market environment, government R\&D support, etc.

According to the principle of data availability and indicator comprehensiveness, the indexes in the following table are selected as influencing factors of technological innovation, as shown in Table 1.

Table 1. Influencing factors and measurement indicators description

\begin{tabular}{|c|c|c|c|}
\hline Driving Force & Influence Factor & Code & Measurement Indicator \\
\hline $\begin{array}{l}\text { Technical } \\
\text { Innovation } \\
\text { Performance }\end{array}$ & & $\mathrm{Y}$ & $\begin{array}{l}\text { Patent applications of high-tech industry enterprises } \\
\text { (piece) }\end{array}$ \\
\hline \multirow{2}{*}{$\begin{array}{l}\text { Central } \\
\text { Driving Force }\end{array}$} & \multirow{2}{*}{$\begin{array}{l}\text { Innovation } \\
\text { Investment }\end{array}$} & $V_{1}$ & $\begin{array}{l}\text { R\&D expenditure of high-tech industry enterprises } \\
\text { (10000 yuan) }\end{array}$ \\
\hline & & $V_{2}$ & $\begin{array}{l}\text { R\&D personnel full time equivalent of high-tech } \\
\text { industry enterprises ( } 10000 \text { man-year) }\end{array}$ \\
\hline \multirow{4}{*}{$\begin{array}{l}\text { Internal } \\
\text { Driving Force }\end{array}$} & Enterprise Scale & $V_{3}$ & $\begin{array}{l}\text { The average revenue from the enterprise's principal } \\
\text { business ( } 100 \text { million yuan) }\end{array}$ \\
\hline & $\begin{array}{l}\text { Property Right } \\
\text { Structure }\end{array}$ & $V_{4}$ & $\begin{array}{l}\text { The proportion of the principal business revenue from } \\
\text { state-owned and state-controlled enterprises (\%) }\end{array}$ \\
\hline & \multirow{2}{*}{$\begin{array}{l}\mathrm{R} \& \mathrm{D} \\
\text { Expenditure } \\
\text { Structure }\end{array}$} & $V_{5}$ & $\begin{array}{l}\text { The proportion of expenditure for acquisition of foreign } \\
\text { technology }(\%)\end{array}$ \\
\hline & & $V_{6}$ & $\begin{array}{l}\text { The proportion of expenditure for assimilation of } \\
\text { technology }(\%)\end{array}$ \\
\hline \multirow{3}{*}{$\begin{array}{l}\text { External } \\
\text { Driving Force }\end{array}$} & $\begin{array}{l}\text { Foreign Direct } \\
\text { Investment }\end{array}$ & $V_{7}$ & $\begin{array}{l}\text { The proportion of the principal business revenue from } \\
\text { foreign funded enterprises (\%) }\end{array}$ \\
\hline & $\begin{array}{l}\text { Government } \\
\text { Support }\end{array}$ & $V_{8}$ & $\begin{array}{l}\text { The proportion of government funds in enterprise } \\
\text { intramural } \mathrm{R} \& \mathrm{D} \text { expenditure }(\%)\end{array}$ \\
\hline & Market Structure & $V_{9}$ & $\begin{array}{l}\text { The proportion of the principal business revenue from } \\
\text { large-sized enterprises (\%) }\end{array}$ \\
\hline
\end{tabular}




\subsection{Data and data description}

High-tech enterprises refer to the continuous research and development and transformation of technological achievements in the high-tech fields supported by the state to form the core independent intellectual property rights of enterprises, which is knowledge-intensive, technology-intensive economic entity. Taking Chinese high-tech enterprises as the research object, this paper explores the temporal and spatial differences of the influence of different factors on technological innovation activities.

The empirical data are the technological innovation activities of enterprises in the hightech industries of 31 provinces of China from 2009 to 2016. The data are collected from China Statistical Yearbook on High Technology Industry and China's National Bureau of Statistics (2019). Due to the missing or incomplete data of some provinces (Tibet, Xinjiang, Qinghai and Inner Mongolia provinces), the technical innovation data of 27 provinces from 2009 to 2016 were finally used, among which, data from 2009 to 2015 (7/8 of the total data) were employed as training data, and the data in 2016 (1/8 of the total data) were employed as testing data. Statistical data about measurement indicators are shown in Table 2.

Table 2. Data description of measurement indicators $(N=216)$

\begin{tabular}{|c|c|c|c|c|c|c|}
\hline Indicator & $\mathrm{N}$ & Minimum & Maximum & Mean & S.D. & Variance \\
\hline$V_{1}$ & 216 & 5984.6 & 10478879.6 & 739821.450 & 1384992.6883 & 1918204746737.765 \\
\hline$V_{2}$ & 216 & 391.9 & 224334.0 & 21962.679 & 38572.1316 & 1487809336.382 \\
\hline$V_{3}$ & 216 & 0.6992 & 7.4993 & 3.428433 & 1.7468589 & 3.052 \\
\hline$V_{4}$ & 216 & 0.0000 & 0.6950 & 0.190147 & 0.1563522 & 0.024 \\
\hline$V_{5}$ & 216 & 0.0000 & 0.8811 & 0.121261 & 0.1869766 & 0.035 \\
\hline$V_{6}$ & 216 & 0.0000 & 0.4566 & 0.039147 & 0.0613676 & 0.004 \\
\hline$V_{7}$ & 216 & 0.0047 & 0.9247 & 0.386040 & 0.2493021 & 0.062 \\
\hline$V_{8}$ & 216 & 0.0175 & 0.4328 & 0.122866 & 0.1018056 & 0.010 \\
\hline$V_{9}$ & 216 & 0.0000 & 0.8202 & 0.458141 & 0.1889173 & 0.036 \\
\hline $\mathrm{Y}$ & 216 & 18 & 64880 & 4689.31 & 9424.364 & 88818639.601 \\
\hline
\end{tabular}

\subsection{Variables reduction and nonlinear relationship detection}

In addition, the Pearson correlation coefficient between most independent variables reaches a significant level $(p<0.05$ or 0.01$)$, indicating that these variables are correlated with each other and will cause changes of other variables with the change of one variable, so this study adopts the factor analysis method to make dimension reduction with these 9 independent variables, and extract new common factors as the new influencing factor variables KMO's MSA and $\chi^{2}$ were 0.645 and 1220.549 , respectively, which were significant $(p<0.000)$. Therefore, principal component analysis is adopted in this study to eliminate collinearity among variables and reduce the number of variables.

Finally, four factors were extracted from original independent variables: innovation investment, innovation environment, enterprise scale and government support. The accumulated rotation sums of squared loading of factors extracted from original independent variables were $89.696 \%$. The details of factor analysis are shown in Table 3. 
Table 3. Factor analysis results

\begin{tabular}{|c|c|c|c|c|c|}
\hline Factors & Variables & $\begin{array}{l}\text { Factor } \\
\text { Loadings }\end{array}$ & Communality & Eigenvalues & $\begin{array}{c}\text { Explained } \\
\text { Variance }\end{array}$ \\
\hline \multirow{3}{*}{$\begin{array}{l}\text { Market } \\
\text { Environment }\end{array}$} & $V_{3}$ & 0.896 & 0.848 & \multirow{3}{*}{2.183} & \multirow{3}{*}{$27.284 \%$} \\
\hline & $V_{9}$ & 0.879 & 0.867 & & \\
\hline & $V_{7}$ & 0.681 & 0.827 & & \\
\hline \multirow{2}{*}{$\begin{array}{l}\text { Innovation } \\
\text { Investment }\end{array}$} & $V_{2}$ & 0.963 & 0.980 & \multirow{2}{*}{1.969} & \multirow{2}{*}{$24.607 \%$} \\
\hline & $V_{1}$ & 0.962 & 0.978 & & \\
\hline \multirow{2}{*}{$\begin{array}{l}\text { Government } \\
\text { Support }\end{array}$} & $V_{8}$ & 0.914 & 0.861 & \multirow{2}{*}{1.792} & \multirow{2}{*}{$22.400 \%$} \\
\hline & $V_{4}$ & 0.901 & 0.859 & & \\
\hline \multirow{2}{*}{$\begin{array}{l}\text { Foreign } \\
\text { Technology } \\
\text { Spillover }\end{array}$} & $V_{5}$ & 0.949 & 0.956 & \multirow{2}{*}{1.232} & \multirow{2}{*}{$15.405 \%$} \\
\hline & $V_{7}$ & 0.513 & 0.827 & & \\
\hline \multicolumn{2}{|c|}{ Total explained variance } & \multicolumn{4}{|c|}{$89.696 \%$} \\
\hline
\end{tabular}

By drawing the graphs of nonlinear functions for the extracted common factors and dependent variable, it can be found that except the partial linear relationship of common factors 2 , the other three common factors all have complex nonlinear relationship with dependent variables.

More specifically, the best nonlinear model for fitting the relationship between $Y$ and factors 1 is Compound, Growth or Exponential model (Adjusted $R^{2}=0.1731$, Std. Error $=$ 1.4160). $Y$ and factors 2 is Cubic model (Adjusted $R^{2}=0.9424$, Std. Error $=2262.0923$ ), $Y$ and factors 3 is Cubic model (Adjusted $R^{2}=0.0313$, Std. Error $=9275.8257$ ), $Y$ and factors 4 is Compound, Growth or Exponential model (Adjusted $R^{2}=0.0437$, Std. Error $=1.5227$ ) (Figure 2).

\section{Empirical analysis}

\subsection{Basic analysis results}

The four common factors and the number of patent applications are regarded as input and output variables respectively, a PSO-GRNN model is established. After the model is trained and tested, other variables remain unchanged, each input variable increases and decreases by $5 \%$ respectively, forming two samples, solving the MIV value of this variable to measure its impact on enterprise technological innovation (Table 4).

Table 4 shows that in descending order according to the influence size, the influencing factors of enterprise technological innovation are innovation investment (MIV $=50.0031$ ), market environment $(\mathrm{MIV}=6.3108)$, government support $(\mathrm{MIV}=-4.9440)$ and foreign

Table 4. The MIV of factor affecting technological innovation

\begin{tabular}{|c|c|c|c|c|}
\hline $\begin{array}{c}\text { Influencing } \\
\text { Factors }\end{array}$ & $\begin{array}{c}\text { Innovation } \\
\text { Investment }\end{array}$ & $\begin{array}{c}\text { Market } \\
\text { Environment }\end{array}$ & $\begin{array}{c}\text { Government } \\
\text { Support }\end{array}$ & $\begin{array}{c}\text { Foreign Technology } \\
\text { Spillover }\end{array}$ \\
\hline Average Value & 50.0031 & 6.3108 & -4.9440 & 2.3606 \\
\hline
\end{tabular}



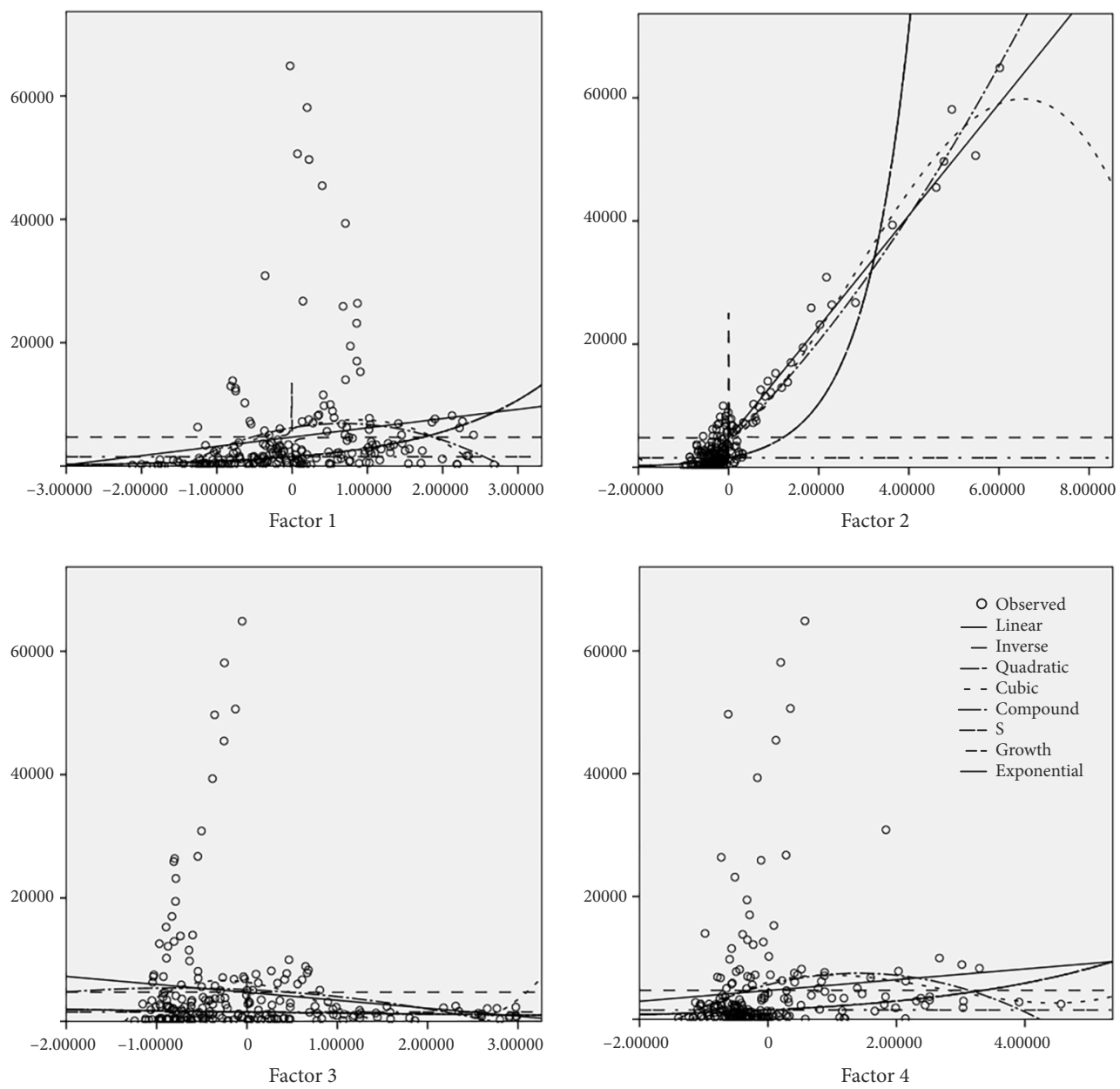

Figure 2. Nonlinear function fitting diagram of $Y$ and $F_{1}-F_{4}$

technology spillover (MIV = 2.3606) in sequence. Among them, only government support is a negative impact, the other three factors are positive impact, and the impact of innovation investment is much higher than the other three factors. The above conclusion proves Hypothesis 1-4.

\section{Regional disparity analysis}

1) General Situation

According to the differences of economic development level and geographical environment, China can be divided into three regions: Eastern China (Yellow area), Central China (Green area) and Western China (Blue area), as shown in Figure 3.

The statistics show that the patent applications $(Y)$ in Eastern, Central and Western China are 827655,109251 and 75985 respectively, accounting for $81.71 \%, 10.79 \%$ and $7.50 \%$, which 


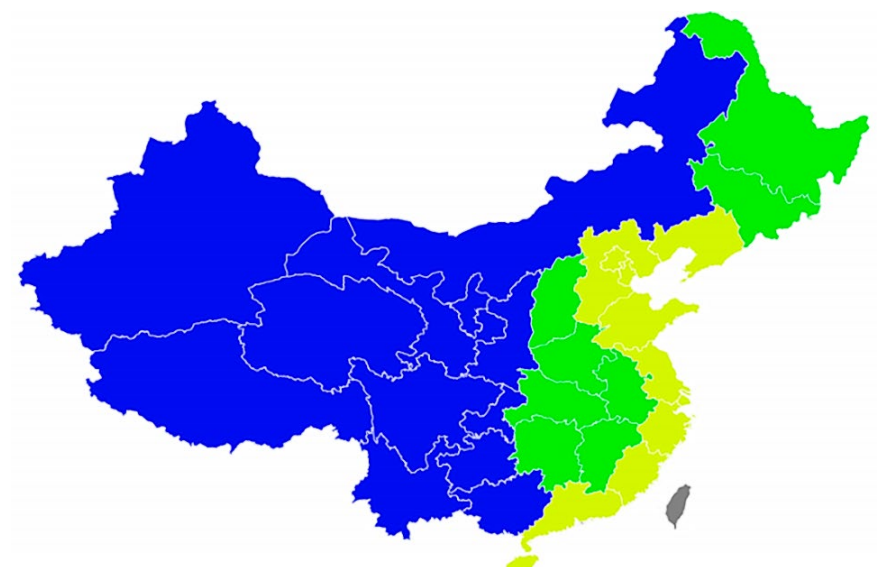

Figure 3. China's three major economic regions

indicates technological innovation mainly concentrates on Eastern China, with little in Central and Western China. Huge technological innovation gap exists between Eastern China and Central-Western China.

The MIV of influencing factors were compiled and calculated in different economic regions of China, then ANOVA was employed to analyze whether there were significant differences of innovation investment, market environment, government support and foreign technology spillover among the three regions. As shown in Table 6, there were significant differences of innovation investment and government support among the three regions, but there were not significant differences of market environment and foreign technology spillover.

Table 5. The regional MIV of factors affecting industrial technological innovation

\begin{tabular}{|c|c|c|c|c|c|c|}
\hline Variables & Regions & Mean & SD & Average & F-value & Sig. \\
\hline \multirow{3}{*}{ Innovation Investment } & Eastern China & 134.2790 & 92.6596 & \multirow{3}{*}{50.0031} & \multirow{3}{*}{9.3488} & \multirow{3}{*}{0.0064} \\
\hline & Central China & -12.9237 & 9.3195 & & & \\
\hline & Western China & -2.9493 & 3.5867 & & & \\
\hline \multirow{3}{*}{ Market Environment } & Eastern China & 15.6799 & 37.5789 & \multirow{3}{*}{6.3108} & \multirow{3}{*}{0.3856} & \multirow{3}{*}{0.7095} \\
\hline & Central China & 3.8278 & 11.2492 & & & \\
\hline & Western China & -4.0887 & 1.1902 & & & \\
\hline \multirow{3}{*}{ Government Support } & Eastern China & -2.5021 & 5.1029 & \multirow{3}{*}{-4.9440} & \multirow{3}{*}{7.8316} & \multirow{3}{*}{0.0644} \\
\hline & Central China & -13.1777 & 0.3598 & & & \\
\hline & Western China & -0.0678 & 3.3296 & & & \\
\hline \multirow{3}{*}{$\begin{array}{l}\text { Foreign Technology } \\
\text { Spillover }\end{array}$} & Eastern China & 1.9990 & 5.1610 & \multirow{3}{*}{2.3606} & \multirow{3}{*}{0.0556} & \multirow{3}{*}{0.9469} \\
\hline & Central China & 1.9608 & 1.4528 & & & \\
\hline & Western China & 3.2576 & 5.4802 & & & \\
\hline
\end{tabular}




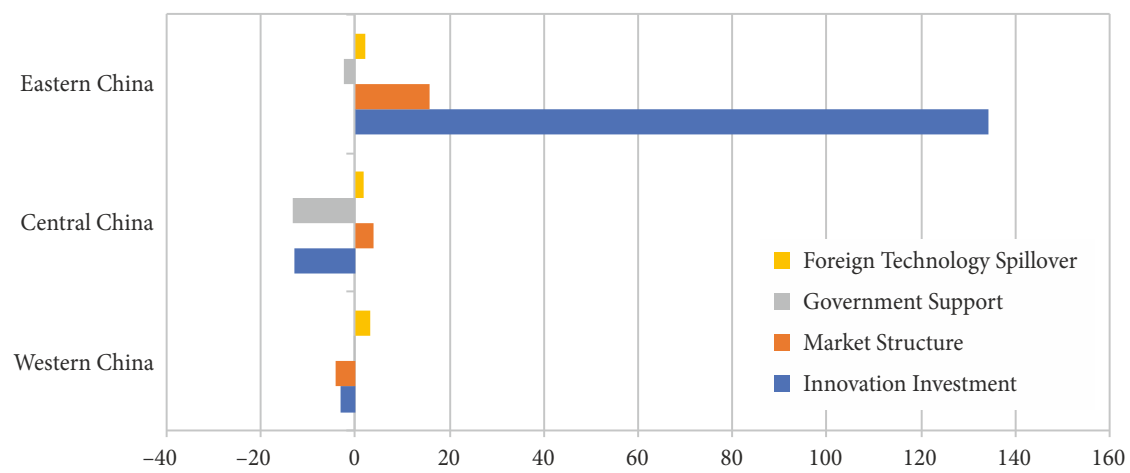

Figure 4. The comparison of influencing factor in different regions

The results confirm the hypotheses $H_{1}$ and $H_{3}$, i.e., the effects of innovation investment and government support have regional differences, but reject the hypotheses $H_{2}$ and $H_{4}$, i.e., the effects of market environment and foreign technology spillover all have regional differences.

Table 5 and Figure 4 show that innovation investment is the decisive factor of technological development in Eastern China. Government support and innovation investment have greatly restricted the technological progress in Central China. Foreign technology spillover has significantly promoted the technological development of high-tech enterprises in Western China, but the innovation environment is the biggest limiting factor.

2) Innovation Investment

The MIV of innovation investment in Eastern, Central and Western China is 134.2790, -12.9237 and -2.9493 respectively (Table 5 and Figure 4), which shows that innovation investment in Eastern China has an absolute influence on technological innovation, while innovation investment has a negative influence on Central and Western China.

Furthermore, the LSD (Least Significant Difference) $t$ test was used to explore the MIV differences of innovation investment among three regions (Table 6). The results showed that the difference in the impact of innovation investment between Eastern China and Central China was significant $(p=0.0038)$, and the difference between Eastern China and Western China was also significant $(p=0.0057)$, but the difference between Central China and Western China was not significant $(p=0.7991)$.

Table 6. The multiple comparisons of innovation investment in different regions

\begin{tabular}{|c|c|l|c|c|c|c|}
\hline \multirow{2}{*}{ Test } & \multirow{2}{*}{ Region(I) } & \multirow{2}{*}{ Region(J) } & \multirow{2}{*}{$\begin{array}{c}\text { Mean } \\
\text { Difference (I-J) }\end{array}$} & \multirow{2}{*}{ Sig. } & \multicolumn{2}{|c|}{$95 \%$ Confidence Interval } \\
\cline { 6 - 7 } & & & Lower Bound & Upper Bound \\
\hline \multirow{4}{*}{ LSD } & \multirow{2}{*}{ Eastern China } & Central China & $147.2027^{*}$ & 0.0038 & 61.1340 & 233.2714 \\
\cline { 3 - 7 } & \multirow{2}{*}{ Central China } & Western China & $137.2283^{*}$ & 0.0057 & 51.1596 & 223.2970 \\
\cline { 3 - 7 } & & Eastern China & $-147.2027^{*}$ & 0.0038 & -233.2714 & -61.1340 \\
\cline { 3 - 7 } & \multirow{2}{*}{ Western China } & Eestern China & -9.9744 & 0.7991 & -96.0431 & 76.0943 \\
\cline { 3 - 7 } & & Central China & $-137.2283^{*}$ & 0.0057 & -223.2970 & -51.1596 \\
\hline
\end{tabular}

Note: ${ }^{\star}$ The mean difference is significant at the 0.10 level. 


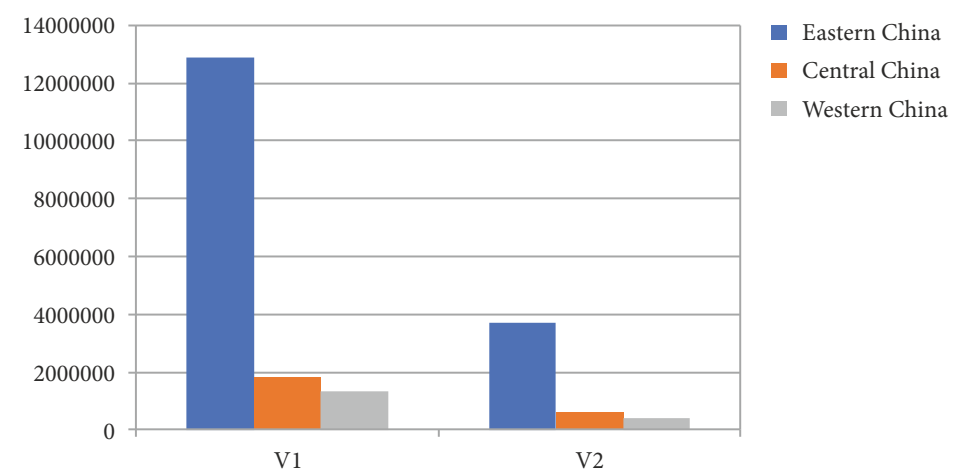

Figure 5. The statistics of innovation investment in different regions

Additionally, the statistics indicates that $\mathrm{R} \& \mathrm{D}$ expenditure $\left(V_{1}\right)$ and $\mathrm{R} \& \mathrm{D}$ personnel full time equivalent $\left(V_{2}\right)$ account for $80.67 \%$ and $78.54 \%$ in Eastern China, $11.09 \%$ and $12.88 \%$ in Central China, $8.24 \%$ and $8.58 \%$ in Western China (Figure 5). Clearly, innovation investment is primarily concentrated in East China and less in Central and Western China, there are extraordinary differences in innovation investment among three regions in China.

The above results prove that innovation investment is the decisive factor of technological innovation, which is consistent with the view of most scholars, but innovation investment is mainly concentrated in Eastern China, Central and Western China are seriously scarce. The huge regional differences of innovation investment and the shortage of innovation investment in Central and Western China have led to the positive impact of innovation investment in Eastern China, while in Central and Western China, it has a negative impact.

3) Market Environment

The MIV of market environment in Eastern, Central and Western China is 15.6799, 3.8278 and -4.0887 severally, indicating that the contribution of the market environment in Eastern China is greater than that in Western China, the market environment in Western China has a negative effect on technological innovation, and is the biggest obstacle restricting technological innovation (Table 5 and Figure 4).

The LSD (Least Significant Difference) $t$ test was used to explore the MIV differences of market environment among three regions (Table 7). The results showed that the difference in the impact of market environment between Eastern China and Central China was not significant $(p=0.6371)$, and the differences between Eastern China and Western China $(p=$ $0.4472)$, Central China and Western China $(p=0.7499)$ were also not significant.

The statistics also show that the average revenue from the enterprise's principal business $\left(V_{3}\right)$, the proportion of the principal business revenue from large-sized enterprises $\left(V_{9}\right)$ and the proportion of the principal business revenue from foreign funded enterprises $\left(V_{7}\right)$ are 3.9695, 51.31\% and 56.52\% in Eastern China, 3.0371, 44.91\% and 30.44\% in Central China, $3.0758,39.16 \%$ and $22.14 \%$ in Western China (Figure 6). Statistics mean the high-tech enterprise scale in Eastern China is the largest, while the high-tech enterprise scale in Central China is the smallest. In Eastern China, large enterprises and foreign-funded enterprises dominate the market. In Western China, the proportion of large enterprises and foreignfunded enterprises is the lowest. 
Table 7. The multiple comparisons of market environment in different regions

\begin{tabular}{|c|c|l|c|c|c|c|}
\hline \multirow{3}{*}{ Test } & \multirow{2}{*}{ Region(I) } & Region(J) & \multirow{2}{*}{$\begin{array}{c}\text { Mean } \\
\text { Difference (I-J) }\end{array}$} & \multirow{2}{*}{ Sig. } & \multicolumn{2}{|c|}{$95 \%$ Confidence Interval } \\
\cline { 5 - 7 } & & & & Lower Bound & Upper Bound \\
\hline \multirow{4}{*}{ LSD } & \multirow{2}{*}{ Eastern China } & Central China & 11.8521 & 0.6371 & -60.2553 & 83.9594 \\
\cline { 3 - 7 } & \multirow{2}{*}{ Central China } & Western China & 19.7686 & 0.4472 & -52.3388 & 91.8760 \\
\cline { 3 - 7 } & Eastern China & -11.8521 & 0.6371 & -83.9594 & 60.2553 \\
\cline { 3 - 7 } & Western China & 7.9165 & 0.7499 & -64.1908 & 80.0239 \\
\cline { 3 - 7 } & \multirow{2}{*}{ Western China } & Eastern China & -19.7686 & 0.4472 & -91.8760 & 52.3388 \\
\cline { 3 - 7 } & Central China & -7.9165 & 0.7499 & -80.0239 & 64.1908 \\
\hline
\end{tabular}

Note: ${ }^{\star}$ The mean difference is significant at the 0.10 level.

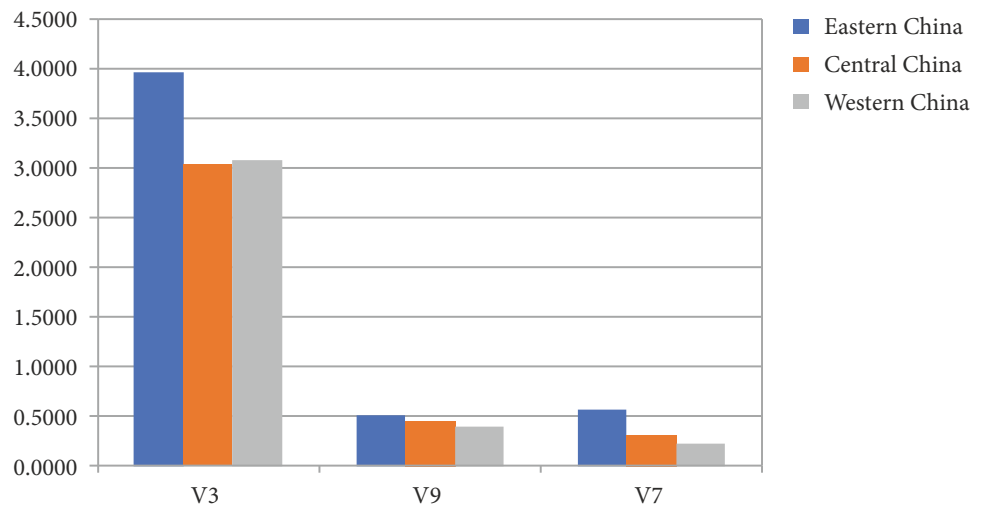

Figure 6. The statistics of market environment in different regions

Enterprises are the main entities of technological innovation. The above empirical results prove that both large-sized enterprise and foreign funded enterprise are conducive to promoting regional technological innovation, enterprise scale is also positively correlated with technological innovation level. The market environment in Eastern China is better than that in the Central and Western China, but the regional gap in the market environment is smaller than that of innovation investment.

\section{4) Government Support}

The MIV of government support in Eastern, Central and Western China is -2.5021, -13.1777 and -0.0678 respectively (Table 5 and Figure 4 ), that indicates that in three regions of China, especially in Central China, government support is negatively correlated with technological innovation, Chinese government has participated too much in the R\&D activities of enterprises, which has brought adverse effects on the efficiency of technological innovation of enterprises.

The LSD (Least Significant Difference) $t$ test was used to explore the MIV differences of government support among three regions (Table 8). The results showed that the difference in the impact of government support between Eastern China and Central China was signifi- 
cant $(p=0.0563)$, and the difference between Central China and Western China was also significant $(p=0.0338)$, but the difference between Eastern China and Western China was not significant $(p=0.5393)$.

The statistics point out that the proportion of government funds in enterprise intramural $\mathrm{R} \& \mathrm{D}$ expenditure $\left(V_{8}\right)$ and the proportion of the principal business revenue from stateowned and state-controlled enterprises $\left(V_{4}\right)$ are $9.24 \%$ and $13.10 \%$ in Eastern China, $13.23 \%$ and $18.42 \%$ in Central China, $15.54 \%$ and $27.74 \%$ in Western China (Figure 7 ), which shows that in East China, the proportion of government R\&D support funds and state-owned enterprises is the lowest, followed by Central China and the highest in Western China.

The above analysis indicates that government $\mathrm{R} \& \mathrm{D}$ support funds have crowding out effects on enterprises' own R\&D funds. Meanwhile, state-owned enterprise has the principalagent problem and its technological development efficiency is lower than that of private and foreign enterprises. These two reasons lead to the negative impact of government support on technological innovation

5) Foreign Technology Spillover

The MIV of foreign technology spillover in Eastern, Central and Western China is 1.999, 1.9608 and 3.2576 respectively (Table 5 and Figure 4), which shows that foreign technology

Table 8. The multiple comparisons of government support in different regions

\begin{tabular}{|c|c|l|c|c|c|c|}
\hline \multirow{3}{*}{ Test } & \multirow{2}{*}{ Region(I) } & Region(J) & \multirow{2}{*}{$\begin{array}{c}\text { Mean } \\
\text { Difference (I-J) }\end{array}$} & \multirow{2}{*}{ Sig. } & \multicolumn{2}{|c|}{$95 \%$ Confidence Interval } \\
\cline { 5 - 7 } & & & Lower Bound & Upper Bound \\
\hline \multirow{4}{*}{ LSD } & \multirow{2}{*}{ Eastern China } & Central China & $10.6756^{*}$ & 0.0563 & -0.5392 & 21.8905 \\
\cline { 3 - 7 } & \multirow{2}{*}{ Central China } & Western China & -2.4343 & 0.5393 & -13.6492 & 8.7805 \\
\cline { 3 - 7 } & & Eastern China & $-10.6756^{*}$ & 0.0563 & -21.8905 & 0.5392 \\
\cline { 3 - 7 } & \multirow{2}{*}{ Western China } & Eestern China & $-13.1010^{*}$ & 0.0338 & -24.3248 & -1.8951 \\
\cline { 3 - 7 } & & Central China & $13.1010^{*}$ & 0.0338 & 1.8951 & 24.3248 \\
\hline
\end{tabular}

Note: ${ }^{*}$ The mean difference is significant at the 0.10 level.

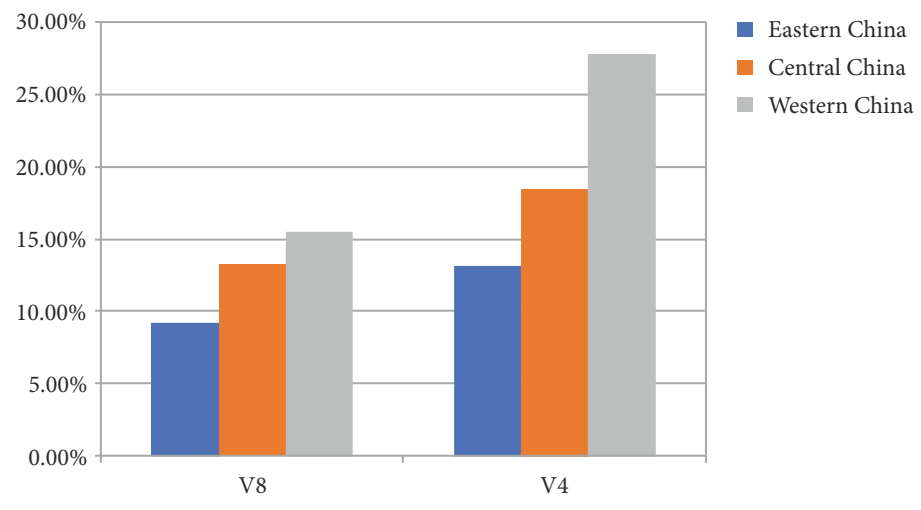

Figure 7. The statistics of government support in different regions 
acquisition and foreign direct investment have technology spillover effects, which have a positive impact on China's technological innovation, especially in Western China, foreign technology has the greatest positive impact on the technological innovation.

The LSD (Least Significant Difference) $t$ test was used to explore the MIV differences of foreign technology spillover among three regions (Table 9). The results showed that the differences in the impact of foreign technology spillover between Eastern China and Central China ( $p=0.9937)$, Eastern China and Western China $(p=0.7947)$ and Central China and Western China ( $p=0.7886$ ) were not significant.

The statistics also reveal that the proportion of expenditure for acquisition of foreign technology $\left(V_{5}\right)$ in Eastern, Central and Western China is $23.44 \%, 5.55 \%$ and $3.15 \%$ respectively. The proportion of the principal business revenue from foreign funded enterprises $\left(V_{7}\right)$ of Eastern, Central and Western China is 56.52\%, 30.44\% and 22.14\% (Figure 8). In Eastern China, foreign technology acquisition and foreign direct investment are the largest, followed by Central China and the least in Western China. Serious shortage of foreign technology acquisition and foreign direct investment exist in Western China.

The above results confirm $H_{1}-H_{4}$ hypothesis, that is, there are regional variations in the impact of innovation investment, market environment, government support and foreign technology spillover.

Table 9. The multiple comparisons of foreign technology spillover in different regions

\begin{tabular}{|c|c|c|c|c|c|c|}
\hline \multirow{2}{*}{ Test } & \multirow{2}{*}{ Region(I) } & \multirow{2}{*}{ Region $(\mathrm{J})$} & \multirow{2}{*}{$\begin{array}{c}\text { Mean } \\
\text { Difference (I-J) }\end{array}$} & \multirow{2}{*}{ Sig. } & \multicolumn{2}{|c|}{ 95\% Confidence Interval } \\
\hline & & & & & Lower Bound & Upper Bound \\
\hline \multirow{6}{*}{ LSD } & \multirow{2}{*}{ Eastern China } & Central China & 0.0382 & 0.9937 & -14.0486 & 14.1250 \\
\hline & & Western China & -1.2586 & 0.7947 & -15.3454 & 12.8282 \\
\hline & \multirow{2}{*}{ Central China } & Eastern China & -0.0382 & 0.9937 & -14.1250 & 14.0486 \\
\hline & & Western China & -1.2968 & 0.7886 & -15.3836 & 12.7900 \\
\hline & \multirow{2}{*}{$\begin{array}{l}\text { Western } \\
\text { China }\end{array}$} & Eastern China & 1.2586 & 0.7947 & -12.8282 & 15.3454 \\
\hline & & Central China & 1.2968 & 0.7886 & -12.7900 & 15.3836 \\
\hline
\end{tabular}

Note: ${ }^{\star}$ The mean difference is significant at the 0.10 level.

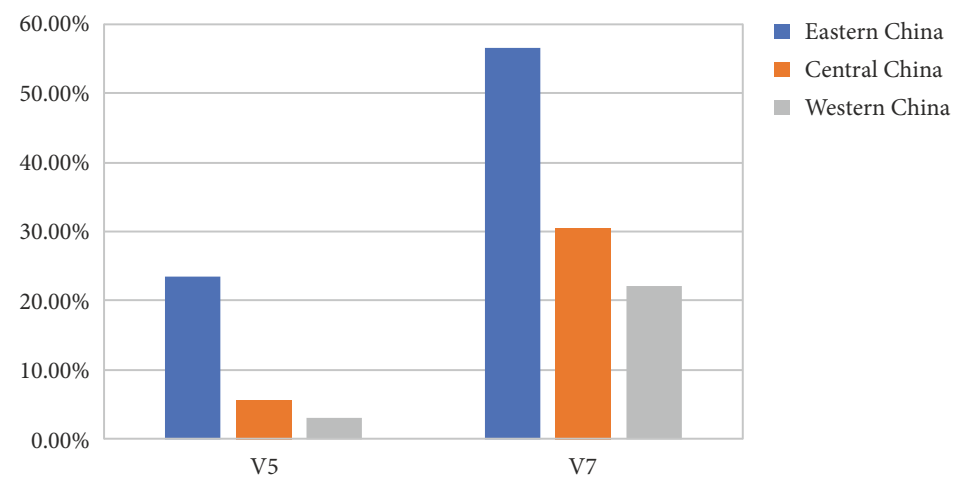

Figure 8. The statistics of foreign technology spillover in different regions 


\section{Conclusions and policy implications}

In view of the current arguments and even contradictory views on the influencing factors of technological innovation, this paper established a PSO-GRNN model with better fitting of nonlinear relations, used sensitivity analysis to measure the effect size and regional variation of different factors on the technological innovation of China's high-tech industries, finally drew different conclusions from previous studies, which were summarized as follows.

In descending order according to the absolute value of impact size, the influencing factors of technological innovation are innovation investment, market environment, government support and foreign technology spillover, of which only government support has negative effects, the other three factors have positive effects.

Innovation investment is the decisive factor of technological innovation. However, the effect size of innovation investment varies from region to region. Innovation resources (R\&D expenditure and employees) are mainly concentrated in Eastern China, while the Central and Western China are seriously lacking, which restricts the technological innovation in the Central and Western China.

Market environment has a positive impact on technological innovation on the whole. The market environment mainly considers the influence of enterprise scale and foreign enterprises on technological innovation. The enterprise scale is positively correlated with the enterprise technological innovation level, which proves that the larger the enterprise scale, the more beneficial it is for the enterprise to bear the innovation risk and monopolize the innovation income. Foreign-invested enterprises have a positive influence on the technological innovation of the enterprise, which indicates that foreign direct investment has technology spillover effect. However, due to the existence of regional gaps in innovation environment, large enterprises and foreign-funded enterprises are mainly concentrated in Eastern China and the least in the Western China, which makes the innovation environment show positive effect in Eastern and Central China and negative influence in Western China, particularly, the market environment is the biggest obstacle that restricts technological innovation in Western China.

Government support has negative impacts on technological innovation in China's three major regions, especially, it is the biggest constraint factor for technological innovation of high-tech enterprises in Central China, which confirms the view that government R\&D support funds have crowding-out effect on enterprises' own funds, and also confirms the view that the inherent principal-agent problem in state-owned enterprises will lead to a decline in innovation efficiency.

Foreign technology acquisition and foreign direct investment will both form technology spillover effect and promote the technological innovation of local enterprises. However, the spillover effect of foreign technologies has regional differences. Eastern China has the weakest impact and Western China has the strongest impact. The reason is that foreign technology acquisition and foreign direct investment are seriously lacking in the Western China, while East China has the most sufficient.

According to the above research conclusions, this paper puts forward the following countermeasures and suggestions to promote the technological innovation of Chinese enterprises. 
Firstly, R\&D investment is the most fundamental determinant of technological innovation. Increasing $R \& D$ expenditure, optimizing the structure of $R \& D$ employees and allocating $\mathrm{R} \& \mathrm{D}$ expenditure and employees rationally are effective ways for high-tech enterprises to improve innovation output and enhance independent innovation ability.

Secondly, Chinese market environment has a positive effect on technological innovation in general, but serious regional differences in innovation environment exist. Chinese governments especially in Western China need to optimize the business environment, attract more foreign-funded enterprises, cultivate more local enterprises, and appropriately expand enterprise scale to promote technological innovation of local enterprises.

Thirdly, Chinese government should adjust the direction and mode of government R\&D support funds, reduce intervention and give freedom to enterprise $R \& D$ activities. For the direction of government R\&D support funds, government should increase the financial support for basic research, because it has the characteristics of public goods, but for application research, such as new product development, the utilization efficiency of government support funds is lower than that of enterprises' own funds, investment should be reduced. Government support models can be divided into financial support and equity investment. The former is a direct way, while the latter is an indirect way. Equity investment is generally more effective. Therefore, for the support mode, Chinese government should shift from direct financial support to indirect support modes such as equity investment, tax incentives and financial subsidies to improve the utilization efficiency of R\&D funds and the innovation performance of enterprises.

Fourthly, Chinese government should continue to expand the import of high-tech products, attract foreign direct investment, and cultivate the ability to absorb foreign technology and conduct suitable policies according to regional differences.

Although this study has made contributions, there are still some deficiencies. First of all, each specific factor affecting technological innovation should be further investigated in detail, such as R\&D expenditure and personnel, enterprise scale, market competition and monopoly, state-owned property rights, foreign technology acquisition and foreign direct investment. The mechanism of these factors is controversial, and it is necessary to further analyze the temporal and spatial differences of the impacts of these factors on technological innovation. In addition, the PSO-GRNN model is not widely applied in other fields, its accuracy and robustness should be further tested and verified through applications in other commercial and economic fields.

\section{Notations}

GRNN - Generalized Regression Neural Network.

PSO - Particle Swarm Optimization Algorithm.

MIV - Mean Impact Value.

MLR - Multiple Linear Regression.

RBF - Radial Basis Function.

ANN - Artificial Neural Network.

FDI - Foreign Direct Investment. 


\section{Acknowledgements}

The author acknowledges the support from the Hebei Key Laboratory of Strategic Critical Mineral Resources, Hebei GEO University, China.

\section{Author contributions}

Yongli Zhang conducted data collection, data calculation, and wrote program modules to make drafts and made a grammar check.

\section{Disclosure statement}

The authors declare that they have no conflicts of interest.

\section{References}

Aghion, P., Bloom, N., Blundell, R., Griffith, R., \& Howitt, P. (2005). Competition and innovation: An inverted-U relationship. The Quarterly Journal of Economics, 120(2), 701-728. https://doi.org/10.1093/qje/120.2.701

Alarcón, S., \& Sánchez, M. (2013). External and internal R\&D, capital investment and business performance in the Spanish agri-food industry. Journal of Agricultural Economics, 64(3), 654-675. https://doi.org/10.1111/1477-9552.12015

Alfaro, L. (2016). Gains from foreign direct investment: Macro and micro approaches. The World Bank Economic Review, 30(Suppl. 1), S2-S15. https://doi.org/10.1093/wber/lhw007

An, J., He, G., Qin, F., Li, R., \& Huang, Z. (2018). A new framework of global sensitivity analysis for the chemical kinetic model using PSO-BPNN. Computers \& Chemical Engineering, 112, 154-164. https://doi.org/10.1016/j.compchemeng.2018.02.003

Cao, M. S., Pan, L. X., Gao, Y. F., Novák, D., Ding, Z. C., Lehký, D., \& Li, X. L. (2017). Neural network ensemble-based parameter sensitivity analysis in civil engineering systems. Neural Computing and Applications, 28(7), 1583-1590. https://doi.org/10.1007/s00521-015-2132-4

China’s National Bureau of Statistics. (2019). 2009-2016 National Data [OL]. http://www.stats.gov.cn/

Cho, Y. (2020). The effects of knowledge assets and path dependence in innovations on firm value in the Korean semiconductor industry. Sustainability, 12(6), 2319. https://doi.org/10.3390/su12062319

Coad, A., Segarra, A., \& Teruel, M. (2016). Innovation and firm growth: Does firm age play a role? Research Policy, 45(2), 387-400. https://doi.org/10.1016/j.respol.2015.10.015

Dazheng, W. (2009). Encourage the introduction of technology or encourage self-innovation. Science \& Technology Progress and Policy, 24.

Demirel, P., \& Mazzucato, M. (2012). Innovation and firm growth: Is R\&D worth it? Industry and Innovation, 19(1), 45-62. https://doi.org/10.1080/13662716.2012.649057

$\mathrm{Du}$ J., Liu, Y., \& Diao, W. (2019). Assessing regional differences in green innovation efficiency of industrial enterprises in China. International Journal of Environmental Research and Public Health, 16(6), 940. https://doi.org/10.3390/ijerph16060940

Guo, D., Guo, Y., \& Jiang, K. (2016). Government-subsidized R\&D and firm innovation: Evidence from China. Research Policy, 45(6), 1129-1144. https://doi.org/10.1016/j.respol.2016.03.002

Holland, J. H. (1992). Adaptation in natural and artificial systems. MIT Press. https://doi.org/10.7551/mitpress/1090.001.0001 
Hong, J., Feng, B., Wu, Y., \& Wang, L. (2016). Do government grants promote innovation efficiency in China's high-tech industries? Technovation, 57, 4-13. https://doi.org/10.1016/j.technovation.2016.06.001

$\mathrm{Hu}$, A. G. (2001). Ownership, government R\&D, private R\&D, and productivity in Chinese industry. Journal of Comparative Economics, 29(1), 136-157. https://doi.org/10.1006/jcec.2000.1704

$\mathrm{Hu}, \mathrm{R}$., Wen, S., Zeng, Z., \& Huang, T. (2017). A short-term power load forecasting model based on the generalized regression neural network with decreasing step fruit fly optimization algorithm. Neurocomputing, 221, 24-31. https://doi.org/10.1016/j.neucom.2016.09.027

Hua, Z., Wang, Y., Xu, X., Zhang, B., \& Liang, L. (2007). Predicting corporate financial distress based on integration of support vector machine and logistic regression. Expert Systems with Applications, 33(2), 434-440. https://doi.org/10.1016/j.eswa.2006.05.006

Huang, Q., Jiang, M. S., \& Miao, J. (2016). Effect of government subsidization on Chinese industrial firms' technological innovation efficiency: A stochastic frontier analysis. Journal of Business Economics and Management, 17(2), 187-200. https://doi.org/10.3846/16111699.2015.1061590

Huang, Y., Salike, N., Yin, Z., \& Zeng, D. Z. (2017). Enterprise innovation in China: Does ownership or size matter? (RIEI Working Papers 2017-06). Xian Jiaotong-Liverpool University, Research Institute for Economic Integration. https://ideas.repec.org/p/xjt/rieiwp/2017-06.html

Jefferson, G. H., Huamao, B., Xiaojing, G., \& Xiaoyun, Y. (2006). R\&D performance in Chinese industry. Economics of Innovation and New Technology, 15(4-5), 345-366. https://doi.org/10.1080/10438590500512851

Jiang, J. L., Su, X., Zhang, H., Zhang, X. H., \& Yuan, Y. J. (2013). A novel approach to active compounds identification based on support vector regression model and mean impact value. Chemical Biology \& Drug Design, 81(5), 650-657. https://doi.org/10.1111/cbdd.12111

Kennedy, J., \& Eberhart, R. (1995). Particle swarm optimization. In Proceedings of ICNN'95 - International Conference on Neural Networks (Vol. 4, pp. 1942-1948). https://doi.org/10.1109/ICNN.1995.488968

Koc, T., \& Ceylan, C. (2007). Factors impacting the innovative capacity in large-scale companies. Technovation, 27(3), 105-114. https://doi.org/10.1016/j.technovation.2005.10.002

Ladlani, I., Houichi, L., Djemili, L., Heddam, S., \& Belouz, K. (2012). Modeling daily reference evapotranspiration (ET 0) in the north of Algeria using generalized regression neural networks (GRNN) and radial basis function neural networks (RBFNN): A comparative study. Meteorology and Atmospheric Physics, 118(3-4), 163-178. https://doi.org/10.1007/s00703-012-0205-9

Lewandowska, A., Pater, R., \& Cywiński, L. (2019). Determinants of business innovation in the Regional Innovation System context. Policy implications for a less developed region. Studia Regionalne i Lokalne, 1(75), 5-27. https://doi.org/10.7366/1509499517501

Li, D., Chau, P. Y., \& Lai, F. (2010). Market orientation, ownership type, and e-business assimilation: Evidence from Chinese firms. Decision Sciences, 41(1), 115-145. https://doi.org/10.1111/j.1540-5915.2009.00261.x

Li, G. S., \& Shen, K. R. (2011). Study on technological introduction, independent R\&D and innovation performance in China. Journal of Finance and Economics, 11.

Li, K., Qu, J., Pan, W., Ai, H., \& Jia, P. (2020). Modelling technological bias and productivity growth: A case study of China's three urban agglomerations. Technological and Economic Development of Economy, 26(1), 135-164. https://doi.org/10.3846/tede.2020.11329

Lin, J., \& Zhang, P. (2006). Appropriate technology, technological selection, and economic growth in developing countries. China Economic Quarterly, 5(4), 985.

Luo, W., \& Fu, Z. (201)3. Application of generalized regression neural network to the agricultural machinery demand forecasting. Applied Mechanics and Materials, 278-280, 2177-2182. https://doi. org/10.4028/www.scientific.net/AMM.278-280.2177

Marchioni, A., \& Magni, C. A. (2018). Investment decisions and sensitivity analysis: NPV-consistency of rates of return. European Journal of Operational Research, 268(1), 361-372.

https://doi.org/10.1016/j.ejor.2018.01.007 
Mei, L., \& Shao, W. (2016). The effect of firm size on regional innovation efficiency in China. Modern Economy, 7(10), 1035-1049. https://doi.org/10.4236/me.2016.710106

Noesselt, N. (2017). Governance change and patterns of continuity: Assessing China's "New Normal". Journal of Chinese Political Science, 22(3), 341-355. https://doi.org/10.1007/s11366-017-9487-6

Pavitt, K., Robson, M., \& Townsend, J. (1987). The size distribution of innovating firms in the UK: 1945-1983. The Journal of Industrial Economics, 35(3), 297-316. https://doi.org/10.2307/2098636

Pfeffer, J., \& Salancik, G. R. (2003). The external control of organizations: A resource dependence perspective. Stanford University Press.

Schumpeter J., \& Backhaus U. (2003). The theory of economic development. In J. Backhaus (Ed.), Joseph Alois Schumpeter. The European heritage in economics and the social sciences (Vol. 1, pp. 61-116). Springer, Boston, MA. https://doi.org/10.1007/0-306-48082-4_3

Shefer, D., \& Frenkel, A. (2005). R\&D, firm size and innovation: an empirical analysis. Technovation, 25(1), 25-32. https://doi.org/10.1016/S0166-4972(03)00152-4

Smith, N., \& Thomas, E. (2017). Regional conditions and innovation in Russia: The impact of foreign direct investment and absorptive capacity. Regional Studies, 51(9), 1412-1428. https://doi.org/10.1080/00343404.2016.1164307

Stock, G. N., Greis, N. P., \& Fischer, W. A. (2002). Firm size and dynamic technological innovation. Technovation, 22(9), 537-549. https://doi.org/10.1016/S0166-4972(01)00061-X

Szczygielski, K., Grabowski, W., Pamukcu, M. T., \& Tandogan, V. S. (2017). Does government support for private innovation matter? Firm-level evidence from two catching-up countries. Research Policy, 46(1), 219-237. https://doi.org/10.1016/j.respol.2016.10.009

Tseng, S. C., \& Hung, S. W. (2013). A framework identifying the gaps between customers' expectations and their perceptions in green products. Journal of Cleaner Production, 59, 174-184.

https://doi.org/10.1016/j.jclepro.2013.06.050

Wan, L., Luo, B., Li, T., Wang, S., \& Liang, L. (2015). Effects of technological innovation on ecoefficiency of industrial enterprises in China. Nankai Business Review International, 6(3), 226-239. https://doi.org/10.1108/NBRI-01-2015-0003

Wang, Y., \& Guo, Y. (2008). An empirical study on R\&D input and output efficiency of listed companies. Industrial Economics Research, 6(6), 44-52.

Wang, Y., Ning, L., Li, J., \& Prevezer, M. (2016). Foreign direct investment spillovers and the geography of innovation in Chinese regions: The role of regional industrial specialization and diversity. Regional Studies, 50(5), 805-822. https://doi.org/10.1080/00343404.2014.933800

Wu, J., Ma, Z., \& Zhuo, S. (2017). Enhancing national innovative capacity: The impact of high-tech international trade and inward foreign direct investment. International Business Review, 26(3), 502-514. https://doi.org/10.1016/j.ibusrev.2016.11.001

Wu, Y. B. (2008). The determinants of innovation - Empirical study based on Chinese manufacturing industry. The Journal of World Economy, 2, 46-58.

Xiao, W., Pan, J. D., \& Liu, L. Y. (2018). China's industrial structure upgrade in the "New Normal": Empirical test and determinants. The Singapore Economic Review, 63(04), 1037-1058. https://doi.org/10.1142/S021759081742005X

Zhang, H., \& Shi, J. (2011). On the technical efficiency of new product in Chinese provincial industry. Economic Research Journal, 1, 83-96.

Zhong, W., Yuan, W., Li, S. X., \& Huang, Z. (2011). The performance evaluation of regional R\&D investments in China: An application of DEA based on the first official China economic census data. Omega, 39(4), 447-455. https://doi.org/10.1016/j.omega.2010.09.004

Zhu, Y., Wang, Z., Qiu, S., \& Zhu, L. (2019). Effects of environmental regulations on technological innovation efficiency in China's industrial enterprises: A spatial analysis. Sustainability, 11(7), 2186. https://doi.org/10.3390/su11072186 